\title{
ASSESSING THE INTEGRATED PEST MANAGEMENT PRACTICES OF PENNSYLVANIA, U.S., LANDSCAPE COMPANIES
}

\author{
by James C. Sellmer', Nancy Ostiguy², Kathleen M. Kelley ${ }^{3}$, and Kelli Hoover ${ }^{2}$
}

\begin{abstract}
A mail survey was conducted in 2000 to determine awareness and use of Integrated Pest Management (IPM) practices by landscape companies in Pennsylvania, U.S. Participants answered questions pertaining to awareness of common practices, the frequency at which IPM practices were employed, and aspects of monitoring and pest management decision-making processes. Three distinct IPM practitioner segments were identified and labeled "IPM savvy" (companies more likely to employ IPM practices), "part-time IPMers" (companies that employed some IPM strategies), and "reluctant IPMers" (companies least likely to employ IPM strategies). The "part-time IPMers" and "reluctant IPMers" segments represented a substantial part of the industry (68\%). Overall, Pennsylvania landscape companies are aware of IPM practices and monitor for insects and mites, diseases, and weeds. However, confidence in identification of specific pests, site analyses, use of diagnostic and monitoring tools, employing beneficial organisms, and maintaining permanent records of pests and management strategies employed remain low. Continued education is warranted to enhance pest monitoring skills, diagnostic tools, pest identification, treatment options, and record keeping. The results of this survey clearly show that landscape companies still have need of demonstrable evidence that the implementation of IPM practices is cost effective and offers marketing benefits to their company.
\end{abstract}

Key Words. Integrated Pest Management; Plant Health Care; survey; cluster analysis; segmentation.

Landscape Integrated Pest Management (IPM) and its key components have been actively discussed, employed, and reviewed in the scientific and trade journals since the 1980s (Raupp and Noland 1984; Raupp 1985; Rhoads 1985; Nielsen 1990). Within these discussions, the reasons for adopting IPM practices in the landscape have been well described and include potential health and safety hazards of pesticide use in urban and suburban communities, increased pest resistance with repeated pesticide use, and indiscriminate use of cover sprays without consideration of biology or the economics of the application (Raupp and Noland 1984; Smith and Raupp 1986). Smith and Raupp (1986) demonstrated that through scouting, record keeping, targeted control activities involving conventional and biopesticides, and mechanical control practices (e.g., pruning) on large community properties, spray reductions of $87 \%$ and $79 \%$ could be achieved in consecutive years after implementation of the IPM program. In addition, cost reductions of $31 \%$ and $12 \%$ were also recorded during the IPM program time period.

Many papers have discussed the components of an IPM program (Raupp 1985; Nielsen 1990). Four key components of IPM are (1) site analysis to identify pest and cultural problems, including key plants and key pests; (2) scouting a minimum of four times a year with a maximum scouting interval of every 2 weeks during the growing season for insects, weeds, diseases, rodents, and cultural problems utilizing visual inspection and traps (for insects); (3) permanent record keeping that documents pests and affected plants, environmental conditions, timing of the problem, and control methods employed; and (4) following treatment, periodically evaluating the effect of control.

There is a great deal of information available on the rationale for and benefits of implementing IPM in the landscape, prompting many groups, including arborists, extension educators, landscape managers, trade associations, and citizen groups, to adopt IPM strategies and promote IPM training. IPM education is conveyed through numerous forums, including organized educational programs, newsletters, Web sites, and industry publications.

In 1999, Pennsylvania, U.S., ranked seventh in the nation in the number of landscape service establishments, with 3,011 licensed firms, and fifth nationally in the number of employees working in the industry $(14,040)$ (Willits and Shields 2001). The Pennsylvania nursery industry includes certified nursery growers and dealers. Nursery dealers are defined as businesses engaged primarily in buying and selling nursery stock. In 2000, the Pennsylvania Department of Agriculture (PDA) listed 4,380 certified dealers in the state consisting of chain stores, collectors, distributors, greenhouse producers, hobbyists, mail order companies, seedling dealers, landscape contractors, landscape nurseries, and garden centers (Commonwealth of Pennsylvania 2000). Of these 4,380 certified dealers, 2,247 were represented by landscape contractors, landscape nurseries, and garden centers. The largest concentration of landscape contracting, nursery, and garden center operations is in southeastern Pennsylvania, followed by the southwestern and south-central regions of the state. In all cases, landscape companies are concentrated around the major metropolitan 
areas of Philadelphia, Pittsburgh, and Harrisburg. Willits and Shields (2001) reported that $82 \%$ of gross income of landscape contractors in Pennsylvania was generated by design, installation, and maintenance activities, while $17 \%$ of garden centers' income was associated with design and installation and $8 \%$ with maintenance.

In 2000, a survey of the Pennsylvania landscape industry was conducted to determine their understanding of IPM concepts and practices and their use of these practices. For this survey, participants included registered landscape contractors, garden centers, and landscape nurseries from the PDA's certified nursery dealers mailing list. Survey questions focused on awareness of IPM practices, implementation of IPM by landscape companies, level of pest monitoring activities employed, pest presence and abundance that influence pest management practices, control practices employed, issues that inhibit use of IPM, and where participants acquire IPM educational information and recommendations.

\section{MATERIALS AND METHODS}

A 15-page survey consisting of eight sections and 42 questions was mailed to 1,800 certified dealers chosen at random from the landscape contractors, landscape nurseries, and garden center operations identified on the PDA's Bureau of Plant Industry 2000 certified nursery dealer's mailing list. Adapted from the Dillman method (Dillman 2000) the survey was first mailed on 24 April 2000, with a reminder postcard mailed on 15 May 2000. A second survey and letter were mailed to participants in mid-June 2000.

\section{Data Analysis}

Cluster analysis (SPSS Inc., Chicago, IL) was used to determine whether meaningful IPM practitioner segmentations could be created, based on participants' answers to several questions. Cluster analysis has been used by researchers to define consumer segments related to their preference for horticultural products such as edible flowers (Kelley et al. 2001) and geraniums (Behe et al. 1999), perceived consumer plant knowledge (Hardy et al. 1999), and perceived consumer knowledge about Plant Health Care and IPM practices (Sellmer et al. 2003). Variables used for clustering were based on survey respondents' knowledge about IPM and cultural practices. Cluster group responses were then analyzed to determine the participants' level of knowledge of and use of IPM techniques and practices.

It is our goal that this information be available to researchers and extension personnel to help focus their educational efforts on topics of which landscapers lack adequate knowledge. By using K-means, clusters of sizes 2 , 3 , and 4 were examined using eight cluster algorithms. After examining each cluster size, the three-cluster solution was selected to develop practitioner segments.

\section{RESULTS AND DISCUSSION General}

Of the 1,800 landscape firms who received a survey, 185 completed them, resulting in a response rate of $10 \%$, slightly below the benchmark response rate of $11 \%$ for direct-mail surveys (Reed 1999). The most likely reason for the low response rate was due in part to mailings of the first survey and subsequent survey communications reaching companies during their busy spring and early summer season.

Among respondents, 74\% reported attaining a degree beyond high school. Over half (52\%) were responsible for pest monitoring activities for their business. Forty-six percent reported having between 11 and 20 years of industry experience. Seventy-seven percent of participants were owners or partners in the business. A majority of respondents (87\%) were involved in pest management decisions for the business. Twenty-five percent reported gross sales for 1998 of over $\$ 500,000$, and $63 \%$ of the operations have been in business over 10 years.

The top ten most recognized IPM practices among respondents were selecting resistant plant varieties (87\%); monitoring (83\%); removing heavily infested landscape plants (82\%); removing plant debris (81\%); matching plants to site conditions (80\%); using insecticidal soaps, horticultural oils, or repellents (77\%); releasing beneficial insects, mites, or other organisms (74\%); pruning (74\%); keeping records (72\%); and mulching (68\%). Less than half of respondents routinely employed IPM (45\%), while 40\% employed IPM strategies some of the time. In comparison, only $28 \%$ of landscape maintenance and lawn care firms surveyed in Atlanta, Georgia, U.S. (Hubbell et al. 2001) were employing IPM practices. Although a higher percentage of Pennsylvania respondents reported that they routinely employ IPM strategies than in Atlanta, there still appear to be opportunities for extension education to increase the use of monitoring, pest identification, site analysis, cultural practices, and record keeping. Our results suggest that the targets of education in these areas are those companies who responded that they "sometimes" (40\%), "rarely" (11\%), or "never" (4\%) employ IPM strategies.

Site analyses, monitoring, and record keeping are three key concepts of landscape IPM practices (Raupp 1985; Rhoads 1985; Nielsen 1990). Of these three concepts, respondents were aware of the importance of monitoring; over 96\% monitor for insects and mites, diseases, and weeds combined on a weekly basis during the growing season.

Inconsistencies in recognition and implementation of IPM practices were found among respondents. For example, $80 \%$ recognized the importance of matching plants to the intended site; however, only 34\% reported conducting site analysis on these sites. Similarly, $72 \%$ recognized the importance of keeping pest records, although only 20\% did so. If site analyses and record keeping are not implemented, 
significant limitations confront the landscape manager in their ability to (1) properly select and site plants to ensure survival and success (Hartman et al. 2000; Lilly 2001); (2) identify key pests, key plants, and potential problem areas for developing management plans (Nielsen 1990); and (3) retain and interpret valuable monitoring information when making management decisions. Not taking these steps can result in the unnecessary expenditure of valuable financial and human resources each time a problem reappears at a site where previous documentation of the problem could have expedited diagnosis and treatment. These survey results suggest that greater educational programming may be necessary to demonstrate the practical, cultural, and financial importance of site analyses and record keeping.

Of respondents who monitor for specific pests, a majority monitor for insects and mites during the growing season (82\%), followed by weeds (78\%) and diseases (73\%). Weekly monitoring was most common for each pest (37\% insect and mites, $33 \%$ weeds, and 28\% diseases) followed by daily monitoring (28\%, 23\%, and 23\%, respectively). Weekly monitoring of insects and mites, weeds, and diseases meets the recommendations of Raupp and Cornell (1988) for monitoring frequency in the U.S. mid-Atlantic region. Few respondents (7\%) employ growing degree days (GDD) as a tool for initiating insect and mite monitoring activities, even though resources are available for horticulturists interested in employing GDD (Orton 1989). In southeastern Pennsylvania, a cooperative group of growers, landscapers, arboreta and botanic garden personnel, and extension educators have initiated the Penn-Del IPM Research Group, which cooperatively compiles and publishes GDD weekly during the growing season (Hoover 2002). The survey results, however, suggest that efforts to educate landscapers about the use of GDD and plant phenology can and should be expanded and reinforced within Pennsylvania.

Less than $20 \%$ of respondents base their insect and mite, disease, and weed monitoring on reports or notification from the PDA plant inspectors $(13 \%, 11 \%$, and $6 \%$, respectively), Penn State Extension educators (17\%, 12\%, and 7\%, respectively), or colleagues $(16 \%, 15 \%$, and $8 \%$, respectively) on pest problems in their area. Fewer utilize the scouting reports that are available by telephone for insect $(5 \%)$, disease $(5 \%)$, or weeds ( $1 \%$ ) for initiating monitoring activities. Although few scouting reports are available for weeds, scouting reports on arthropods and some diseases are available through cooperative IPM sources in Pennsylvania (for example, sepaipm.cas.psu.edu and paipm.cas.psu. edu/ipminfo.html).

Confidence in accurately identifying insects and mites, diseases, and weeds was relatively low, with respondents reporting greatest confidence in "always" accurately identifying weeds (39\%), followed by insects and mites (29\%) and diseases (15\%). Greater than half (51\% to $60 \%$ ) "usually" accurately identified the insect or mite, weed, or disease problem. Confidence in "always" accurately identifying growing-condition problems on the landscape site was also only $25 \%$, with $60 \%$ "usually" identifying the growingcondition problem. These results suggest that additional educational programming in insect and mite, disease, weed, and cultural or environmental problems should be developed and implemented to increase IPM practitioner confidence and accuracy.

Visual inspection, traps (i.e., sticky cards, pheromones, and black-light traps), foliage samples, and indicator plants are some of the techniques available to monitor insect and mite pests in the landscape (Raupp 1985). Among these techniques, a majority of the respondents (96\%) employ visual inspection followed by foliage samples (42\%) and indicator plants (41\%). Few (17\%) use traps in their monitoring regime. The survey did not ask why traps are not being used, but this lack of use may be partly due to a lack of understanding or information about the benefits or methods of using traps.

Less than one-third of participants reported sending disease and insect samples to a diagnostic lab for identification (18\% insect and mite, 28\% disease, respectively). Less than half of the respondents related insect and mite (38\%) or disease (42\%) presence to current and forecasted environmental conditions. Greater than half of respondents related arthropod (57\%) and disease (75\%) presence to the plant's condition. In addition, $70 \%$ related plant variety to disease presence. Thirty-two percent of respondents reported identifying the presence of beneficial insect or mites during their monitoring activities.

Incidence, severity, and time of year were predominantly used in deciding whether to treat for arthropods and diseases, with severity being most common at $89 \%$ and $87 \%$, respectively. Less than $30 \%$ considered phenological indicators prior to treating for arthropods and diseases. Preventive blanket sprays for insects (25\%), cost of treatment for diseases (28\%), and customer expectation for disease control (28\%) were not important factors in deciding to treat.

Respondents most often considered weed severity in their decision to treat (78\%). A majority of the respondents targeted persistent weed problems in their management activities (78\%), while $61 \%$ reported eradicating perennial weeds before planting. Timing of herbicide applications to ensure effective control is a constant issue in landscape management. One method is to target the vulnerable point in the life cycle of a specific weed; however, only $45 \%$ reported using this technique for weed control. This finding may be partly due to lack of information on the effective time to target specific weeds. A common approach to reducing weed pressure is to prevent germination of weed seeds; $44 \%$ of the respondents reported using geotextile 
fabrics or plastic weed barriers, while 63\% employed preemergence herbicides to achieve this goal.

Among practices "often" used by participants to reduce plant related health issues, matching plants to site conditions was most common (91\%). Weed maintenance was a common activity (91\%), followed by fertilization programs (81\%). Fewer than one-quarter (21\%) of the landscape managers employed drip irrigation at their sites; however, this percentage may increase after the recent multi-year drought in Pennsylvania and the northeastern U.S. Only $28 \%$ reported "often" employing soil tests. When asked how often they conduct soil tests, only 14\% tested once a year, while 38\% reported testing less than every other year. Similarly, a majority of the respondents reported "never" (81\%) using foliar nutrient tests to verify plant nutrient levels. This high rate of landscapers who do not employ foliar nutrient analysis may be due to the lack of knowledge or experience in using this diagnostic tool, or it may be that plant nutrition has not been considered as an issue in overall plant health.

Among current pest and disease management practices, few $(9 \%)$ claimed to use beneficial organisms, while over half of respondents claimed to conserve beneficials through their selection of pesticides (51\%) and use of cultural practices (54\%). For insect and mite control, more respondents reported using horticultural oils (46\%) compared to insecticidal soaps (27\%). Few employed natural products (19\%), while 63\% reported to use chemical pesticides.

\section{IPM Practitioner Segments}

Cluster analysis was used to determine whether meaningful IPM practitioner segments could be created, based on participants' answers to several key questions regarding implementation of IPM strategies and practices including monitoring, record keeping, site analysis, and regularity of pesticide applications. Three distinct segments were identified: "IPM savvy," "part-time IPMer," and "reluctant IPMer." Each segment clearly defined what practices are currently used to monitor and control insects/mites, diseases, and weeds, along with cultural practices and site factors.

Reluctant IPMer. Of the three segments, the "reluctant IPMer" group was the largest and least involved in IPM practices. This practitioner segment consisted of 77 participants, or $42 \%$ of respondents, and had a significantly greater number of respondents that rarely implemented IPM strategies (19\%); were least likely to monitor for insects $(57 \%)$ and diseases (52\%) during the growing season; were most likely to not monitor for insects (8\%); were least active in doing complete site analyses (25\%) for each landscape site they manage; were less accurate in identifying specific insects or mites (68\%) and diseases (57\%); and were least likely to relate arthropod presence to condition of the host $(47 \%)$ or to relate disease presence to current or forecasted conditions (33\%) and plant condition (65\%).
Reluctant IPMers were also less likely to consider arthropod severity (81\%) or disease incidence and severity (69\% and $78 \%$, respectively) in deciding when to treat. This segment was also less likely to consider customer expectation of treatment benefit prior to treatment (16\%). Members of this segment were least likely to offer fertilization programs (77\%) or to regularly employ soil testing (20\%) and most likely to not soil test (36\%) or to employ foliar nutrient testing (90\%).

Among current monitoring and control practices, this segment was less active in monitoring diseases and arthropod pests (69\%); least active in using horticultural oils (34\%), chemical pesticides (38\%), and pre-emergence herbicides (51\%); and most likely to "never" spray on a schedule for insect or mites (72\%), diseases (76\%), and weeds (51\%). Overall, the "reluctant IPMer" segment employed few IPM practices and uses few control methods that are either chemical or IPM specific. In addition, this group does not readily apply preventive and diagnostic strategies such as site analysis, soil testing, or foliar nutrient analysis.

IPM Savvy. The second largest segment among respondents accounted for 60 survey participants (32\%) and was designated the "IPM savvy" group. In contrast to "reluctant IPMers," this segment was more likely to monitor for arthropods (88\%), diseases (82\%), and weeds (78\%) during the growing season, with weekly monitoring for diseases (40\%). This group claims to monitor "often" for diseases and pests (97\%), and to identify specific insects (90\%) and diseases (85\%). "IPM savvy" landscapers were most likely to consider plant variety (82\%) during disease monitoring and disease incidence (88\%) in deciding to treat, and to weigh customer expectations that something be done to treat a disease regardless of the benefit (38\%). Culturally, a majority of this segment grew and sold plants hardy to the area (95\%) and employed drip irrigation at their landscape sites (30\%). "IPM savvy" respondents were least likely to spray on a schedule for insect and mites and for diseases, although a majority of respondents reported spraying on a schedule ( $70 \%$ and $72 \%$, respectively). The survey did not allow for follow-up questions regarding scenarios that would prompt scheduled treatments compared to making decisions based on thresholds or monitoring. Further surveying specifically on decision-making may provide more information on what pests and diseases are most likely to trigger a treatment action based on a set spray schedule.

Part-Time IPMer. The third and smallest segment included 49 participants (26\%) that employed some IPM and cultural practices, including using scouting reports for insects or mites (12\%), diseases (12\%), and weeds (4\%) as part of their monitoring program. This segment responded that they "always" accurately identified weed problems $(52 \%)$, related insect or mite presence to host plant condition (69\%), employed preventive blanket sprays to treat 
insects or mites (43\%), offered fertilization maintenance programs (92\%), and currently employ insecticidal and/or horticultural oils (67\%) and horticultural oils (59\%), while also relying on chemical pesticides (92\%). "Part-time IPMers" were most likely to target persistent weed problems (88\%) and employed direct spray and wipe-on application of herbicides to control weeds (71\%). Respondents from this group were most likely to spray on a schedule for arthropods (94\%), employing blanket sprays "often" (25\%) and "sometimes" (43\%), for diseases (89\%) either "always" (4\%), "often" $(25 \%)$, or "sometimes" $29 \%$ ), and for weeds (100\%), with 19\% "always" and 40\% "often" spraying on a schedule.

\section{Trends Among Segments}

The IPM segments revealed important differences in understanding and implementation among the three groups. Segment comparisons also identified similarities among the IPM groups.

A majority claimed to use IPM strategies to some degree from routinely to rarely (96\%). Few respondents relied on outside information from extension, state governmental agencies, or general scouting reports when deciding when and what to monitor. Visual inspection for insects and mites was the monitoring technique of choice for most $(91 \%$ to $100 \%$ ) respondents. Traps were employed by fewer than $20 \%$ for insect and mite monitoring. Lack of documented use of traps provides an opportunity to develop educational programs centered on their effectiveness, deployment, maintenance, and interpretation of results based on the target insect.

Record keeping was employed by fewer than $22 \%$ across the segments, and fewer than half (24\% to $44 \%$ ) conducted complete site analyses for each site. Severity of insect and mite and disease attacks was the predominant consideration for treating ( $81 \%$ to $92 \%$, and $78 \%$ to $93 \%$, respectively), while fewer than $30 \%$ employed indicators such as growing degree days and phenology of nearby flowering plants.

Matching plants to site conditions, using resistant varieties, selling hardy plants, and offering fertilization and weeding programs were common current practices among respondents in each group, while offering drip irrigation and conducting soil tests were less common (14\% to 30\% and $20 \%$ to $40 \%$, respectively). Among insect and mite control practices, fewer than $12 \%$ employed beneficial organisms, while between $41 \%$ and $67 \%$ employed insecticidal soaps and/or horticultural oils, with 34\% to 59\% of the respondents in each practitioner segment employing horticultural oils. This finding suggests that information and recommendations by extension educators on the use of insecticidal soaps and horticultural oils are being received and employed by the practitioners. However, the efficacy, availability, and protocols for employing beneficial insects in the landscape may not be as readily available.
Finally, a majority in all three segments have "never" employed foliage nutrient analysis in their diagnoses of plant problems (73\% to 90\%). This finding suggests that further education on the use, interpretation, and benefits of employing foliar nutrient analyses may be important for adoption of this diagnostic tool.

\section{IPM Practices Relative to Participant Demographics}

One question often asked about survey data is whether demographic differences such as education, business size based on gross sales, or years in business impact the implementation of IPM strategies. To address this question, the survey data were analyzed based on the respondents' education level, gross sales for 1998, and years in business. Education levels were divided into two groups for analysis. One group had formal education up to and including an associate's degree or trade school, and the other group had obtained a bachelor's degree or higher. Businesses with gross sales of up to US\$100,000 were grouped separately from those generating greater than US\$100,001 during 1998. Finally, companies that have been in business up to 14 years comprised one group, while the other group had been in business for 15 or more years. Respondents were evenly split based on education, with 49\% having an associate's degree or less in formal education, while 51\% had obtained a bachelor's degree or higher. Similarly, the businesses were nearly evenly split based on years in business, with $47 \%$ in business for less than or equal to 14 years and $53 \%$ in business for 15 or more years. In contrast, a majority of the businesses reported gross sales for 1998 of greater than US $\$ 100,001$, compared to $35 \%$ grossing up to US\$100,000.

A majority of the respondents represented in these demographic groups reported using IPM strategies to some level, from routinely to rarely in their business (94\% to 98\%). Overall, few significant demographic differences were found with respect to monitoring frequency or techniques, accuracy in identifying pests or cultural problems, record keeping, treatment decision-making practices, cultural management practices, or use of pesticides.

Among educational groups, significant differences were found in two areas: (1) criteria used in making treatment decisions for arthropod pests and (2) use of cultural practices to reduce weeds. Forty-seven percent of respondents with a bachelor's degree or higher considered current and forecasted environmental conditions when deciding to treat for insects and mites, while only $28 \%$ of the respondents with an associate's degree or less employed this practice in their decision-making process. Similarly, $81 \%$ of respondents with higher post-secondary education reported implementing cultural practices to reduce weeds, while $66 \%$ of those with an associate's degree or less employed cultural practices. 
Businesses grossing greater than US $\$ 100,001$ in sales were significantly more likely to monitor for insects or mites (78\%), diseases (74\%), and weeds (73\%) during the growing season. Of these firms, $84 \%$ claimed to monitor often for pests and diseases. These businesses were significantly more likely to have an employee (11\%) or a combination of individuals (47\%) monitoring for pests, while significantly fewer (38\%) of survey participants monitored for pests at the business. Severity of insect and mite infestations was the most common trigger (93\%) for treatment decisions with firms grossing over US $\$ 100,001$, although severity was also important among firms grossing less than US $\$ 100,000$. Soil testing was used by about $33 \%$ of these firms. Fifty-two percent of these firms employed horticultural oils and 69\% employed chemical pesticides compared to less than half of the companies grossing under US\$100,000 (32\% and 48\%, respectively). The companies grossing over US $\$ 100,001$ reported using preemergence herbicides significantly more (68\%) often than the companies grossing US $\$ 100,000$ or less (48\%).

Companies that were in business for 15 years or more were significantly more likely (74\%) to consider time of year when deciding to treat for insects or mites compared to younger businesses (58\%). A hierarchy of importance was evident in both younger and older firms, with severity being the issue of greatest consideration followed by incidence and time of year, phenological indicators, and use of blanket sprays. A similar trend was apparent in the general survey data. Significantly more (39\%) of the older companies ( $\geq 15$ years in business) conducted soil tests compared to $17 \%$ of the younger companies. Older companies reported employing horticultural oils and/or insecticidal soaps (66\%) in the treatment of insects or mites, with $57 \%$ using only horticultural oils. Older companies were likely to "often" apply fungicides on a schedule (17\%) and "always" apply herbicides $(10 \%)$ on a schedule compared to younger companies (6\% and 3\%, respectively).

\section{CONCLUSIONS}

As a whole, landscapers in Pennsylvania have a high awareness of IPM practices; however, inconsistencies were evident between awareness and routine implementation of some practices. For example, respondents were aware of but did not often use several components of IPM including site analysis, record keeping, plant phenological indicators, growing degree days, traps for monitoring insect and mite presence, and diagnostic tools such as soil and foliar nutrient testing. Additional education and demonstration projects should be developed to assist in the adoption of these practices. Continued education is warranted to enhance pest identification and monitoring skills and to encourage alternative pest management activities including the use of beneficial organisms and Plant Health Care practices such as drip irrigation.
Three distinct IPM practitioner segments were identified among Pennsylvania landscape companies. The "reluctant IPMer" appears to be least interested in IPM practices or general management strategies. This finding may be due in part to the scope of their business, which may be mostly lawn maintenance, or due to a reluctance to employ new practices. Focusing educational resources to help this segment to become aware of the financial and environmental benefits of IPM and adopt these strategies may help move the more proactive members of this group into the "part-time IPMer" or "IPM savvy" segments. The "IPM savvy" groups appear proficient and comfortable with their level of monitoring; however, further surveying of this group to explore their reasons for treating on a schedule may aid in improving their decision-making skills. This group will most likely continue to incorporate new ideas into their IPM programs to satisfy their customers' needs, save money, and comply with changing regulations and pesticide registrations. "Part-time IPMers" appear on the verge of becoming "IPM savvy." Education programs designed to build their skills in identification, alternative control options, site analyses, and record keeping will assist this group in reaching the "IPM savvy" level. Few differences were found among respondents based on demographics. Regardless of education, size or duration of the business, there appears to be a disconnect between recognition and implementation of IPM practices.

\section{LITERATURE CITED}

Behe, B., S. Barton, C. Hall, C.D. Safley, and S. Turner. 1999. Consumer preference for geranium flower color, leaf variegation, and price. HortScience 34(4):740-742.

Commonwealth of Pennsylvania. 2000. List of Certified Nurseries and Nursery Dealers and Stock Locator. Commonwealth of Pennsylvania, Department of Agriculture, Bureau of Plant Industry. 305 pp.

Dillman, D.A. 2000. Mail and Internet Surveys: The Tailored Design Method (2nd ed.). Wiley, New York, NY.

Hardy, J., B.K. Behe, T.J. Page, Jr., and R. Schutzki. 1999. Consumer segmentation based on perceived plant knowledge and gardening involvement. Southern Nursery Assoc. Res. Conf. Proc. 44:509-512.

Hartman, J.R., T.P. Pirone, and M.A. Sall. 2000. Pirone's Tree Maintenance (7th ed.). Oxford University Press, New York, NY. 545 pp.

Hoover, G. A. 2002. Collaborative for Integrated Pest Management. Tree Care Industry, 13(11):18-24.

Hubbell, B.J., W.J. Florkowski, R. Oetting, S.K. Braman, and C.D. Robacker. 2001. Implications of lawn care and landscape maintenance firm profiles for adoption of pestmanagement practices. J. Agric. Appl. Econ. 33(1):147-159.

Kelley, K.M., B.K. Behe, J.A. Biernbaum, and K.L. Poff. 2001. Consumer preference for edible-flower color, container size, and price. HortScience 36(4):801-804. 
Lilly, S.J. 2001. Arborists' Certification Study Guide. International Society of Arboriculture, Champaign, IL. $222 \mathrm{pp}$.

Nielsen, D.G. 1990. Landscape integrated pest management. J. Arboric. 16(10):253-259.

Orton, D.A. 1989. Coincide: The Orton System of Pest Management. Plantsmen's Publications, Flossmoor, IL. 189 pp.

Raupp, M.J. 1985. Monitoring: An essential factor to managing pests of landscape trees and shrubs. J. Arboric. 11(12):349-355.

Raupp, M.J., and C.F. Cornell. 1988. Pest prevention: Treating pests to the IPM treatment. Am. Nurseryman 167(3):59-62, 65-67.

Raupp, M.J., and R.M. Noland. 1984. Implementing landscape plant management programs in institutional and residential settings. J. Arboric. 10(6):161-169.

Reed, D. 1999. Mail dominance. Marketing Week 22(45):41-45.

Rhoads, A.F. 1985. Integrated pest management-What's it all about? J. Arboric. 11(12):369-372.

Sellmer, J.C., K.M. Kelley, S. Barton, and D.J. Suchanic. 2003. Assessing consumer knowledge and use of landscape plant health care and integrated pest management practices through a computer-based interactive survey. HortTechnology 13(3):556-561.

Smith, D.C., and M.J. Raupp. 1986. Economic and environmental assessment of an integrated pest management program for community-owned landscape plants. J. Econ. Entomol. 79:162-265.

Willits, F.K., and M. Shields. 2001. Pennsylvania's Green Industry: Its nature and contribution to the state's economy. Department of Agricultural Economics and Rural Sociology, The Pennsylvania State University, University Park, PA. 28 pp.
Acknowledgments. This research was funded in part by an IPM Green Industry Grant from the Pennsylvania Department of Agriculture, Bureau of Plant Industry, Harrisburg, Pennsylvania. We thank Christopher O'Connor, Jason Rosenzweig, Gary Moorman, Greg Hoover, Dave Suchanic, Emelie Swackhamer, Don Narber, Rick Hansen, Sherry Kyne, Lee Bentz, and Edward Rajotte. We extend special thanks to Dr. Rick Bates and Mr. Martin McGann for reviewing an earlier draft of the manuscript.

Journal Paper No. 434 of The Pennsylvania State University, Department of Horticulture.

\author{
1*Associate Professor \\ Department of Horticulture \\ Penn State University \\ University Park, PA 16802, U.S. \\ ${ }^{2}$ Associate Professor \\ Department of Entomology \\ Penn State University \\ University Park, PA 16802, U.S. \\ ${ }^{3}$ Assistant Professor \\ Department of Horticulture \\ Penn State University \\ University Park, PA 16802, U.S. \\ *Corresponding author.
}


Résumé. Un sondage postal a été mené en 2000 afin de déterminer le degré de sensibilisation et d'utilisation des pratiques de gestion intégrée des insectes et des maladies par les entreprises en entretien des espaces verts de Pennsylvanie. Les participants ont répondu à des questions se rapportant à la sensibilisation aux pratiques usuelles, à la fréquence des pratiques de gestion intégrée employées ainsi qu'aux aspects de suivi et de processus de gestion décisionnelle relatifs aux parasites. Trois segments distincts de pratiques de gestion intégrée des insectes et des maladies ont été identifiés et étiquetés comme suit: entreprises qui ont une préférence pour les pratiques de gestion intégrée, entreprises qui emploient certaines stratégies de gestion intégrée, entreprises qui font appel le moins possible à des stratégies de gestion intégrée. Les entreprises qui emploient certaines stratégies de gestion intégrée, ou encore qui n'en emploient que peu ou pas, constituent $68 \%$ du nombre. Globalement, les entreprises dans le domaine de l'entretien des espaces verts en Pennsylvanie sont conscientes des pratiques de gestion intégrée des insectes et des maladies ainsi qu'au suivi des insectes, des acariens, des maladies et des mauvaises herbes. Néanmoins, l'appel à l'identification spécifique des parasites, aux analyses de site, à l'emploi d'outils de diagnostic et de suivi, à l'emploi d'organismes bénéfiques ainsi qu'au maintien de registres permanents des parasites et des stratégies de gestion employées demeure faible. Léducation continue est justifiée pour améliorer les capacités de suivi des parasites ainsi que celles des outils de diagnostic, d'identification des parasites, des options de traitement et d'enregistrement des données. Les résultats de cette enquête démontrent clairement que les entreprises en entretien des espaces verts ont encore besoin de se faire démontrer de manière évidente que l'implantation de pratiques de gestion intégrée des insectes et des maladies est rentable et offre des perspectives intéressantes de bénéfices pour leur entreprise.

Zusammenfassung. Im Jahr 2000 wurde ein Briefumfrage durchgeführt, um Bewusstsein für und Einsatz von IPS-Praktiken bei Landschaftsbauern in Pennsylvania zu bestimmen. Die Teilnehmer beantworteten Fragen, die das Bewusstsein für die allgemeine Praxis betrafen, die Häufigkeit der IPS-Praxis wurde miteinbezogen, sowie die Aspekte der Überwachung und des Entscheidungsfindungsprozesses. Drei verschiedene Segmente von Praktikern wurden identifiziert und benannt: IPM-Savvy (Firmen, die eher zu IPS greifen), Teilzeit IPMler (Firmen, die einige IPM-Strategien anwenden) und Geringfügig IPMler (Firmen, die am wenigsten IPMStrategien anwenden. Die Teilzeit- und Geringfügig IPMler repräsentierten einen substantiellen Teil des Gewerbes mit 86 $\%$.Insgesamt sind sich Landschaftsbaufirmen in Pennsylvanien bewusst, dass es IPM-Strategien und Aufzeichnungen über Schädlingsbefall gibt. Dennoch ist das Vertrauen in die Identifizierung von bestimmten Krankheiten, Satndortanalyse, Gebrauch von Diagnose- und Überwachungseinrichtungen, der Einsatz von Nützlingen und die permanente Aufzeichnung von Krankheiten und ihrer Behandlung immer noch sehr gering. Das rechtfertigt eine kontinuierliche Ausbildung , um die Fähigkeiten der Überwachung, die Diagnosewerkzeuge, die Schädlingsidentifikation und Behandlungsmöglichkeiten zu verbessern. Die Ergebnisse dieser Umfrage zeigen eindeutig, dass die Landschaftsbaufirmen noch immer Bedarf an deutlichen Beweisen haben, dass die Implementierung von IPM-Praktiken wirksam und kostengünstig ist und als Werbemittel für die Firma eingesetzt werden kann.

Resumen. Se condujo una consulta por correo en el 2000 para determinar el uso de prácticas de Manejo Integrado de Plagas (IPM) por compañías en Pennsylvania. Los encuestados respondieron preguntas pertinentes a las prácticas más comunes de IPM, su frecuencia y aspectos de monitoreo y procesos en el manejo de plagas. Se identificaron tres segmentos de participantes, etiquetados: "IMP Savvy" (compañías que más emplean prácticas de IPM); "Part-time IMPers" (compañías que emplean algunas estrategias de IMP); y "Reluctant IPMers" (compañías menos propensas a emplear estrategias de IMP). Los segmentos "Part-time IMPers" y "Reluctant IPMers" representaron una parte sustancial de la industria (68\%). Sobretodo las compañías del paisaje de Pennsylvania están atentas a las prácticas de IMP y monitoreo de insectos y ácaros, enfermedades, y malezas. Sin embargo, el nivel de confianza es bajo en identificación de plagas específicas, análisis del sitio, uso de herramientas de diagnóstico y monitoreo, empleo de organismos benéficos, mantenimiento de registros permanentes sobre plagas y estrategias de manejo empleadas. La educación continua es garantía para realzar las habilidades en las estrategias de manejo, herramientas de diagnóstico, identificación de plagas, opciones de tratamiento y registros. Los resultados de este estudio muestran claramente que las compañías del paisaje tienen aún necesidad de evidencia demostrable de que la implementación de las prácticas de IMP es efectiva en costo y les ofrece beneficios de mercadeo. 